\title{
Influence of Processing Parameters on the Surface Roughness of Solid Wood Cut by Abrasive Water Jet
}

\author{
Hüseyin Pelit, ${ }^{\mathrm{a}, *}$ and Özkan Yaman ${ }^{\mathrm{b}}$ \\ The surface roughness of pine, beech, and oak wood cut in the abrasive \\ water jet (AWJ) system was evaluated for different processing parameters. \\ Wood specimens were prepared in thicknesses of 18, 36, and $54 \mathrm{~mm}$ in \\ both tangential and radial directions. Then the specimens were cut, \\ applying three different feed speeds $(50,100$, and $200 \mathrm{~mm} / \mathrm{min}$ ), three \\ different abrasive flow rates (200, 300, and $450 \mathrm{~g} / \mathrm{min})$, and two different \\ cutting liquid pressures ( 300 and $380 \mathrm{MPa}$ ) with the AWJ system. The $R_{a}$ \\ and $R_{\mathrm{z}}$ roughness values were higher in the tangential cut for pine and oak \\ specimens and in the radial cut for beech wood. Roughness values \\ increased in all specimens with increases in the AWJ feed speed and the \\ wood thickness. In contrast, with increased amounts of abrasive, $R_{a}$ and \\ $R_{\mathrm{z}}$ values of the specimens decreased and surface smoothness tended to \\ increase. Roughness values of pine and oak specimens generally \\ decreased due to the increase in liquid pressure. However, an increase in \\ the roughness of the beech specimens was determined. As a result, the \\ feed speed and wood thickness were the most influential parameters on \\ the roughness of specimens. In contrast, the cutting direction and liquid \\ pressure showed less importance on the roughness.
}

Keywords: Abrasive water jet; Processing parameter; Surface roughness; Wood material

Contact information: a: Department of Wood Products Industrial Engineering, Faculty of Technology, Duzce University; 81620, Duzce, Turkey; b: Bulanik Vocational and Technical Anatolian High School, Department of Furniture and Interior Design, 49500, Muş, Turkey;

*Corresponding author: huseyinpelit@duzce.edu.tr

\section{INTRODUCTION}

The surface quality of wood and wood-based materials is an important criterion in terms of the costs and aesthetic properties of final products. Surface roughness is a basic factor used to determine the surface quality of wood products (Kılıç 2015; Pinkowski et al. 2018). The surface roughness of treated wood products significantly affects later processes such as bonding and finishing (Richter et al. 1995; Hiziroğlu et al. 2014; Söğütlü et al. 2016; Salca et al. 2017; Söğütlü 2017). The surface quality of the processed wood is affected by many factors such as the anatomical properties, density, moisture, processing method, properties of the process, and processing parameters (Örs and Gürleyen 2002; Kilıç et al. 2006; Budakçı et al. 2011; Tiryaki 2014; Sofuoğlu and Kurtoğlu 2015; Hazır et al. 2017; İlçe 2018; Pinkowski et al. 2018).

Conventional machinery used in the woodworking industry for the processing of wood and wood-based materials is losing importance daily. Thanks to developing technology, these machines have been replaced with fully automatic and computercontrolled ones. These next-generation machines used in production are of great importance for businesses in reducing product costs, as they enable the reduction of the 
workforce, acceleration of the production line, and the saving of time. They also enable greater product variety.

Different geometric figures and complex shapes are often preferred in the manufacture of furniture, decoration, and structural joinery products. Some special cutting methods must be applied for the quick and easy fabrication of the products with this feature. Four possible basic processing methods have been specified in the material cut. These methods are saw cutting with linear reverse travel (scroll-saw based), computer numerical controlled (CNC) milling, laser cutting, and abrasive water jet cutting (Kminiak and Gaf 2014). There is a growing interest in the development of processing methods (milling, cutting, etc.) to increase the value and the worth of the wood materials. Recently, water jet technology has been one of the promising options in the processing of wood and woodbased materials (Wang 2012).

Water jet technology is a new non-conventional industrial method that can be used for cutting materials of different properties. The principle of water jet processing technology can be explained as cutting of the workpiece by means of a fluid that mechanically acts on the material (Barcik et al. 2011a; Kvietkova et al. 2014; Oh and Cho 2014; Li et al. 2015). According to different cutting features in water jet technology, two practical methods are used. They are cutting with a pure water jet (WJ) and cutting with an abrasive water jet (AWJ) (Kvietkova et al. 2014; Li et al. 2015). Many different materials can be cut using WJ and AWJ methods (Hashish 1987; Zhong and Han 2002; Akkurt et al. 2004; Aydın et al. 2011; Li et al. 2013; Shanmughasundaram 2014; Hutyrová et al. 2016). However, AWJ technology, which is an improved form of the WJ method for processing harder materials, such as metal, ceramic, and wood, is a more efficient cutting method (Saraçyakupoğlu 2012). The AWJ machining is a mechanical method in which abrasive particles, such as silica sand, garnet, aluminum oxide, silicon carbide, etc., are entrained in high speed waterjet to erode materials from the surface of material (Sreekesh and Govindan 2014). AWJ technology is very suitable for automation, and highly flexible for the cutting of complex shapes from many different materials (Youssef 2016).

The WJ and AWJ technologies are widely used in many industries, such as aerospace engineering, military engineering, automotive industry, building materials and decoration elements, food processing, and underground mining (Li et al. 2018a). These technologies have benefited from a useful cutting method that can be used for cutting many different materials such as marble, metal, glass, plastic, wood, fabric, and paper (Akkurt 2004). It is a simple, clean, and reliable technology, and therefore it serves as an alternative to other cutting methods (Barcik et al. 2011b; Kvietkova 2014). Furthermore, water jet technology is especially suitable for mass production of high-precision pieces of difficult shapes such as marquetry elements, cutting wood panels, and thin pieces of lumber (Gerencsér and Bejó 2007). In processing precious wood, the use of water jet technology has the significant advantages of excellent cutting quality, high efficiency, low cost, environmental protection, and simple system operation, which can reasonably increase utilization rate of the wood (Hou et al. 2014; Ábrahám et al. 2015; Li et al. 2018b). In addition, water jet cutting offers an effective solution to problems such as dust exposure and high noise in conventional woodworking machines (Gerencsér and Bejó 2007). Moreover, in the processing of composite materials produced with synthetic resins and natural fibers, problems arise when the plastic matrix melts and sticks on the cutting tools. This problem can be solved by using water jet technology (Hutyrová et al. 2016).

In this study, solid wood specimens were cut using the AWJ system by applying different process parameters. The effects of variables, such as wood thickness, cutting 
direction, feed speed, abrasive flow rate, and water pressure, on the $R_{\mathrm{a}}$ and $R_{\mathrm{z}}$ roughness values of the wood specimens were analyzed. Thus, it was aimed to determine the most suitable process parameters to obtain smoother surfaces in wood specimens.

\section{EXPERIMENTAL}

\section{Materials}

In this study, Scotch pine (Pinus sylvestris L.), Eastern beech (Fagus orientalis Lipsky), and sessile oak (Quercus petraea Liebl.) wood, which are widely used in the woodwork industry and furniture-decoration applications, were used. Wood materials, which have a moisture content of approximately $12 \%$ to $14 \%$, were selected randomly from a timber company in Düzce, Turkey. Wood specimens were cut from the sapwood in draft sizes of $550 \mathrm{~mm} \times 65 \mathrm{~mm} \times 65 \mathrm{~mm}$ (longitudinal direction $\times$ tangential direction $\times$ radial direction) and in sufficient numbers. Afterwards, the specimens were held in a conditioning cabin (relative humidity (RH) $65 \pm 3 \%$ and $20 \pm 2{ }^{\circ} \mathrm{C}$ ) until they reached a stable weight, after which they were cut to the dimensions of $250 \mathrm{~mm} \times 54 \mathrm{~mm}(\mathrm{~L} \times \mathrm{T}$ or R$)$ and in three different thicknesses $(18 \mathrm{~mm}, 36 \mathrm{~mm}$, and $54 \mathrm{~mm})$ in both tangential and radial directions. The air-dry density values of wood specimens were measured as $541 \mathrm{~kg} / \mathrm{m}^{3}$ for pine, 678 $\mathrm{kg} / \mathrm{m}^{3}$ for beech and $736 \mathrm{~kg} / \mathrm{m}^{3}$ for oak (ISO 13061-2 2014). To keep the wooden specimens stable during the cutting process with AWJ, as shown in Fig. 1, guide holes (diameter: $8 \mathrm{~mm}$ ) were drilled $20 \mathrm{~mm}$ inside the cross-sectional edges of the wood.

Cutting of wood specimens in AWJ system

Both CNC and a console-type AWJ machine (S-HP Consol; CT Cutting Technologies and Machinery Ind. Inc., Tuzla, Istanbul) were used to cut wood specimens with different parameters. Thickness and cutting direction of the wood specimens and the parameters applied in the cutting process are shown in Table 1.

Table 1. Machining Parameters in AWJ Cutting

\begin{tabular}{|c|c|}
\hline Wood Thickness $(\mathrm{mm})$ & $18,36,54$ \\
\hline Wood Cutting Direction & Tangential, radial \\
\hline Feed Speed $(\mathrm{mm} / \mathrm{min})$ & $50,100,200$ \\
\hline Abrasive Mass Flow Rate $(\mathrm{g} / \mathrm{min})$ & $200,300,450$ \\
\hline Liquid Pressure (MPa) & 300,380 \\
\hline AWJ Nozzle Diameter $(\mathrm{mm})$ & 0.76 \\
\hline AWJ Nozzle Length $(\mathrm{mm})$ & 80 \\
\hline
\end{tabular}

To prevent the movement and vibration of the test specimens during the cutting process, the specimens to be cut were fixed by being placed between previously prepared molds. Cutting operations started and ended in the guide holes previously drilled $20 \mathrm{~mm}$ inside the cross-sectional edges of the specimens (Fig. 1). In cutting operations, the AWJ nozzle was adjusted to be $3 \mathrm{~mm}$ up the specimen surface. Garnet (7.5 to 8 Mohs) was used as the abrasive in the water jet.

After the cutting process, the excess part on the ends of the wood specimen was cut using a circular saw machine. Then, the specimens were kept until they reached constant weight under $20 \pm 2{ }^{\circ} \mathrm{C}$ temperature and $65 \pm 3 \% \mathrm{RH}$ conditions, and specimen surfaces were prepared for roughness testing. 

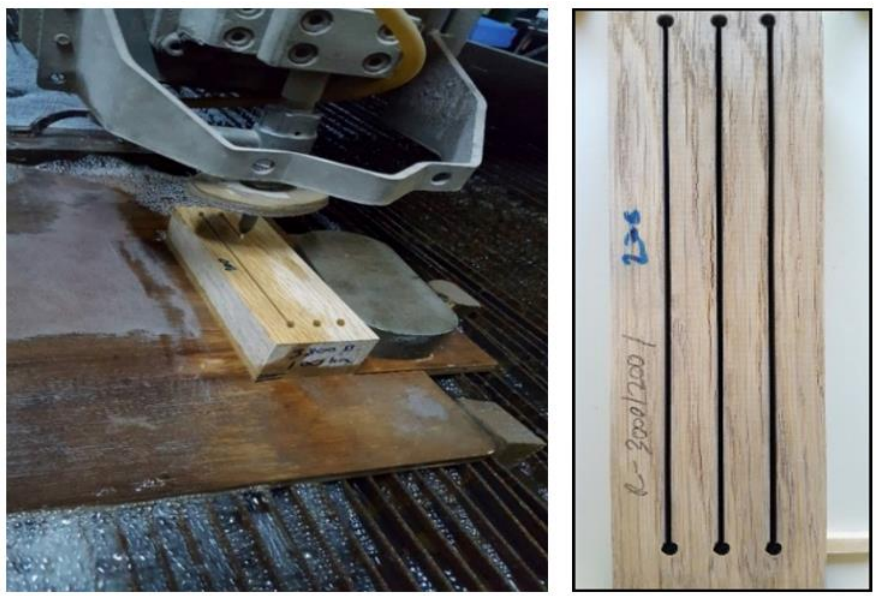

Fig. 1. Cutting wood specimens in AWJ system

\section{Methods}

Determination of surface roughness properties

Surface roughness of wood specimens was determined using a Mitutoyo SurfTest SJ-301 (Mitutoyo® Inc., Kawasaki, Japan) device (Fig. 2). The $R_{\mathrm{a}}, R_{\mathrm{y}}$, and $R_{\mathrm{z}}$ parameters are generally used in the numerical expression of the surface roughness in wood material. The $R_{\mathrm{a}}$ and $R_{\mathrm{z}}$ parameters were measured to evaluate the surface roughness of the specimens according to ISO 4287 (1997). The $R_{\mathrm{a}}$ is the arithmetic mean of the absolute values of the profile departures, and $R_{\mathrm{Z}}$ is the arithmetic mean of the 10-point height of irregularities.
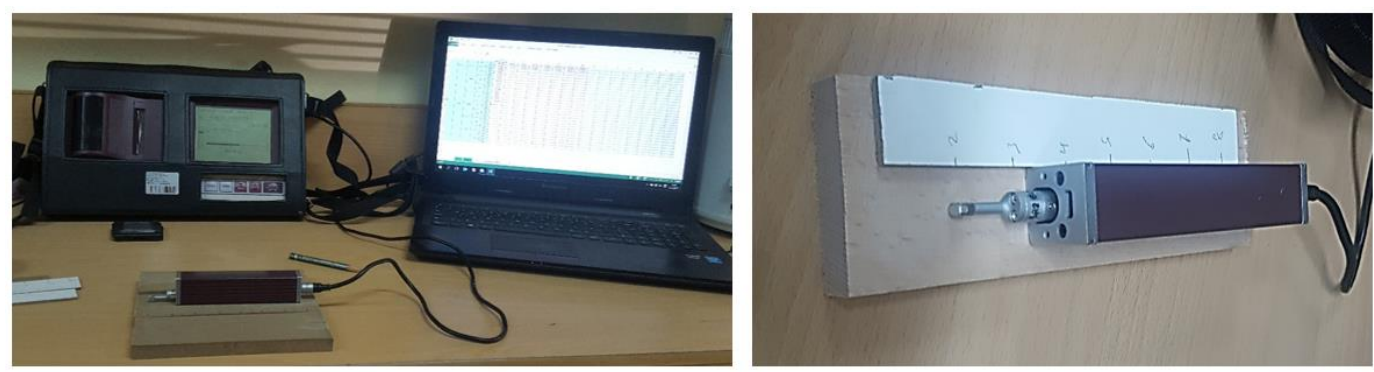

Fig. 2. Roughness measuring device

After setting the roughness measuring device (resolution/range $0.01 \mu \mathrm{m} / 10 \mu \mathrm{m}$ ) to a measuring speed of $15 \mathrm{~mm} / \mathrm{min}$, a measuring step length of $2.5 \mathrm{~mm}$, and a measurement number of 5 , roughness values were measured from eight different points $(n=8)$ at equal intervals on a specific line of the specimen surfaces. The reference lines in the measurements according to the thickness of the wooden specimens are shown in Fig. 3. However, because deep marks or fluctuations occurred after the AWJ cutting on specimen surfaces prepared in $54 \mathrm{~mm}$ thickness, roughness measurement could not be taken on the line determined in these specimens. For this reason, roughness measurements were taken on the $36 \mathrm{~mm}$ depth line instead of $45 \mathrm{~mm}$ in all specimens prepared with a thickness of $54 \mathrm{~mm}$. Roughness measurements were taken in the direction of wood fibers. Approximately 864 measurements (wood thickness of $3 \times$ cutting directions of $2 \times$ feed speed of $3 \times$ abrasive flow rate of $3 \times$ liquid pressure of $2 \times$ measurement repetitions of 8 ) were made for each wood species, and a total of 2592 measurements $(864 \times$ wood species of 3) were taken. 

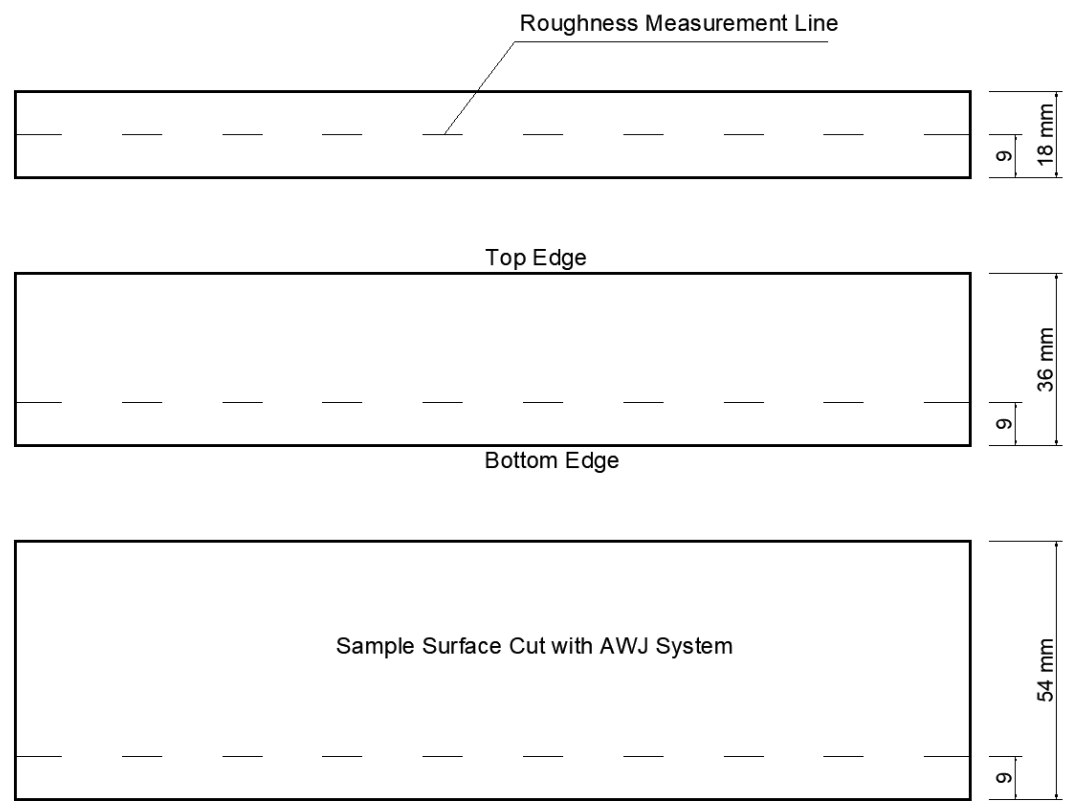

Fig. 3. Roughness measurement lines (locations) according to wood thicknesses

\section{Statistical analyses}

An MSTAT-C 2.1 software program (Michigan State University, East Lansing, MI, USA) was used for statistical evaluations. Analysis of variance (ANOVA) tests were performed to determine the effect of selected machining parameters on surface roughness properties of wood specimens at the 0.05 significance level. Significant differences between the variables were compared using Duncan's test.

\section{RESULTS AND DISCUSSION}

The ANOVA results of surface roughness measurements from pine, beech, and oak specimens cut with different processing parameters in the AWJ cutting system are given in Table 2. The results showed that the effect of cutting direction and thickness, feed speed, abrasive mass flow rate, and cutting liquid pressure factors on $R_{\mathrm{a}}$ and $R_{\mathrm{z}}$ roughness values for each wood species was statistically significant $(\mathrm{p} \leq 0.05)$. Only the effect of cutting liquid pressure on $R_{\mathrm{a}}$ values of oak specimens was found to be insignificant.

Duncan's one-way test results conducted for comparisons of the means of $R_{\mathrm{a}}$ and $R_{\mathrm{z}}$ values in pine, beech, and oak wood specimens cut with different processing parameters in AWJ cutting are given in Tables 3 and 4. In terms of cutting direction, in tangential cut pine and oak wood specimens, and in radial cut beech wood specimens the $R_{\mathrm{a}}$ and $R_{\mathrm{z}}$ values were higher. It can be said that the natural anatomical properties of the wood and the surface texture affected the results. In the literature, it has been stated that the roughness of the wood is dependent primarily on anatomical properties, and secondarily on the machine used in the processing of the wood, process parameters, process methods, and moisture (Sieminski and Skarzynska 1987; Tiryaki 2014). As for wood thickness, the lowest $R_{\mathrm{a}}$ and $R_{\mathrm{z}}$ values were found in 18-mm specimens, while the highest were found in 54-mm specimens. As seen in Figs. 4 and $5, R_{\mathrm{a}}$ and $R_{\mathrm{z}}$ values increased due to the increase in thickness in wood specimens cut using the AWJ system. Compared to the 18 -mm-thick 
pine, beech, and oak specimens, the $R_{\mathrm{a}}$ value of the 54-mm specimens increased $32 \%, 41 \%$, and $49 \%$, respectively; and the $R_{\mathrm{z}}$ value increased $30 \%, 38 \%$, and $46 \%$, respectively. The increases in $R_{\mathrm{a}}$ and $R_{\mathrm{z}}$ roughness values may have resulted from the wider angle formed by the abrasive particles and high-pressure water coming out of the water jet nozzle, and the irregular spread of these particles. In addition, the decrease in the velocity of the highpressure water with abrasive additive applied on the surface of the material over time may have also affected the results. In previous studies, it was reported that as the depth the water jet beam penetration was increased, the deflection amount also increased; and accordingly, as the thickness of the specimens was increased, the roughness on its surface turned into wavy or linear traces. Additionally, it was stated that the decrease in the sharpness of the abrasive particles and fluid pressure in the cutting process using AWJ inevitably results in the emergence of a rougher surface (Ohlsson 1995; Karakurt et al. 2010).

Table 2. ANOVA Results for $R_{a}$ and $R_{z}$ Parameters of Wood Specimens

\begin{tabular}{|c|c|c|c|c|c|}
\hline \multirow{3}{*}{ Wood Species } & \multirow{3}{*}{ Source } & \multicolumn{4}{|c|}{ Surface Roughness } \\
\hline & & \multicolumn{2}{|c|}{$R_{\mathrm{a}}$} & \multicolumn{2}{|c|}{$R_{\mathrm{z}}$} \\
\hline & & F-ratio & $\mathrm{p}$-value & F-ratio & $p$-value \\
\hline \multirow{4}{*}{ Scotch Pine } & $\begin{array}{l}\text { Cutting direction } \\
\text { and thickness }\end{array}$ & 189.1768 & $0.0000^{*}$ & 197.7674 & 0.0000 \\
\hline & Feed speed & 846.6036 & 0.0000 & 832.8585 & 0.0000 \\
\hline & Abrasive flow rate & 24.4491 & 0.0000 & 28.5232 & 0.0000 \\
\hline & Liquid pressure & 39.8036 & 0.0000 & 36.9215 & 0.0000 \\
\hline \multirow{4}{*}{ Eastern Beech } & $\begin{array}{l}\text { Cutting direction } \\
\text { and thickness }\end{array}$ & 174.3728 & 0.0000 & 188.8645 & 0.0000 \\
\hline & Feed speed & 619.7935 & 0.0000 & 682.6197 & 0.0000 \\
\hline & Abrasive flow rate & 64.3292 & 0.0000 & 68.1125 & 0.0000 \\
\hline & Liquid pressure & 32.0913 & 0.0000 & 52.0216 & 0.0000 \\
\hline \multirow{4}{*}{ Sessile Oak } & $\begin{array}{l}\text { Cutting direction } \\
\text { and thickness }\end{array}$ & 286.6223 & 0.0000 & 362.6666 & 0.0000 \\
\hline & Feed speed & 455.9889 & 0.0000 & 587.8457 & 0.0000 \\
\hline & Abrasive flow rate & 49.2667 & 0.0000 & 46.4956 & 0.0000 \\
\hline & Liquid pressure & 1.7245 & NS & 7.1587 & 0.0076 \\
\hline
\end{tabular}

* Significant at 95\% confidence level; NS: not significant

In terms of feed rate in the AWJ cutting, in all wood species the highest $R_{\mathrm{a}}$ and $R_{\mathrm{z}}$ averages were obtained with the feed rate of $200 \mathrm{~mm} / \mathrm{min}$, and the lowest was obtained with the feed rate of $50 \mathrm{~mm} / \mathrm{min}$ (Tables 3 and 4). The $R_{\mathrm{a}}$ and $R_{\mathrm{z}}$ roughness values measured in wood specimens were generally increased due to the increase in feed rate of the AWJ system (Figs. 4 and 5). Compared to the feed rate of $50 \mathrm{~mm} / \mathrm{min}$, in the pine, beech, and oak specimens cut with a feed rate of $200 \mathrm{~mm} / \mathrm{min}$, the $R_{\mathrm{a}}$ value increased $47 \%, 53 \%$, and $41 \%$, respectively, and the $R_{\mathrm{z}}$ values increased $43 \%, 50 \%$, and $40 \%$, respectively. It can be said that the cutting process became more difficult as the feed rate of the AWJ system increased and the rate of pressurized water and abrasive applied on the unit surface decreased, which affected the results. The feed rate in water jet cutting is defined according to the period in which the material is exposed to abrasion or cutting effect. A decrease in the feed rate means that a part of the material is subjected to the water jet effect for a longer time. Thus, on the cut surface, the number of abrasive particles per unit volume increases and accordingly, the surface quality improves (Ohlsson 1995; Karakurt et al. 2010). In a study where the surface roughness of solid wood materials cut using the pure WJ was investigated, it was stated that the surface roughness also increases with the increase of the 
feed rate of the WJ (Gerencsér and Bejó 2007). Additionally, studies on different materials cut using the AWJ system reported that the surface roughness values increase due to the increase in the feed rate (Akkurt et al. 2004; Hascalik et al. 2007; Aydin et al. 2011; Saraçyakupoğlu 2012).

Table 3. Duncan's Test Results for Mean of $R_{a}$ Values

\begin{tabular}{|c|c|c|c|c|c|c|}
\hline \multirow[b]{2}{*}{ Factor } & \multicolumn{2}{|c|}{ Scotch Pine } & \multicolumn{2}{|c|}{ Eastern Beech } & \multicolumn{2}{|c|}{ Sessile Oak } \\
\hline & $\begin{array}{c}\text { Mean } \\
(\mu \mathrm{m})\end{array}$ & SG & $\begin{array}{c}\text { Mean } \\
(\mu \mathrm{m})\end{array}$ & SG & $\begin{array}{c}\text { Mean } \\
(\mu \mathrm{m})\end{array}$ & SG \\
\hline \multicolumn{7}{|c|}{ Cutting Direction and Thickness (mm) } \\
\hline $\mathrm{R}-18$ & 7.13 & $\mathrm{e}$ & 5.67 & $\mathrm{e}$ & 5.56 & $f$ \\
\hline $\mathrm{R}-36$ & 7.67 & $d$ & 6.53 & C & 6.54 & $\mathrm{~d}$ \\
\hline $\mathrm{R}-54$ & 8.97 & $\mathrm{~b}$ & 8.01 & $a$ & 7.87 & $\mathrm{~b}$ \\
\hline $\mathrm{T}-18$ & 7.02 & $\mathrm{e}$ & 5.27 & $f$ & 5.86 & e \\
\hline T-36 & 7.90 & $\mathrm{C}$ & 6.15 & $\mathrm{~d}$ & 6.87 & $\mathrm{c}$ \\
\hline $\mathrm{T}-54$ & 9.75 & $a$ & 7.41 & $\mathrm{~b}$ & 9.12 & $a$ \\
\hline \multicolumn{7}{|c|}{ Feed Speed $(\mathrm{mm} / \mathrm{min})$} \\
\hline 50 & 6.71 & $\mathrm{c}$ & 5.21 & C & 5.80 & c \\
\hline 100 & 7.66 & $\mathrm{~b}$ & 6.34 & $\mathrm{~b}$ & 6.94 & $\mathrm{~b}$ \\
\hline 200 & 9.85 & $\mathrm{a}$ & 7.97 & $\mathrm{a}$ & 8.17 & $\mathrm{a}$ \\
\hline \multicolumn{7}{|c|}{ Abrasive Flow Rate (g/min) } \\
\hline 200 & 8.37 & $a$ & 6.98 & $\mathrm{a}$ & 7.29 & a \\
\hline 300 & 8.03 & $\mathrm{~b}$ & 6.46 & $b$ & 7.08 & $b$ \\
\hline 450 & 7.83 & $\mathrm{c}$ & 6.08 & $\mathrm{c}$ & 6.53 & $\mathrm{c}$ \\
\hline \multicolumn{7}{|c|}{ Liquid Pressure (MPa) } \\
\hline 300 & 8.28 & $\mathrm{a}$ & 6.32 & $\mathrm{~b}$ & 7.01 & $\mathrm{a}$ \\
\hline 380 & 7.87 & $b$ & 6.69 & $\mathrm{a}$ & 6.93 & $\mathrm{a}$ \\
\hline
\end{tabular}

SG: statistical group (different letters denote a significant difference); R: radial; T: tangential

Regarding abrasive flow rate in AWJ system, in all wood species, the highest averages of $R_{\mathrm{a}}$ and $R_{\mathrm{z}}$ were determined with an abrasion rate of $200 \mathrm{~g} / \mathrm{min}$, and the lowest was determined with an abrasion rate of $450 \mathrm{~g} / \mathrm{min}$ (Tables 3 and 4). As can be seen in Figs. 4 and 5, as the amount of abrasive added to the pressurized liquid increased, the overall $R_{\mathrm{a}}$ and $R_{\mathrm{z}}$ roughness values of the wood specimens were observed to decrease. Accordingly, the level of surface smoothness of the specimens tended to increase. Compared to the abrasive flow rate of $200 \mathrm{~g} / \mathrm{min}$, in the pine, beech, and oak specimens cut with an abrasive flow rate of $450 \mathrm{~g} / \mathrm{min}, R_{\mathrm{a}}$ value decreased $6 \%, 13 \%$, and $10 \%$, respectively, and $R_{\mathrm{z}}$ value decreased $7 \%, 12 \%$, and $9 \%$, respectively. It can be said that, in the process of cutting using AWJ, the increase in the effectiveness of the abrasive particles as a result of increasing the amount of these abrasive particles and decreasing the amount of water used had an important effect on the results. In addition, the decrease in the fiber breaks and deformations occurring on the material surface during the cutting process as a result of the increase in the amount of abrasive per unit area may have affected the results. In a previous study, it was stated that the increased amount of abrasive in the AWJ cutting system meant an increased number of abrasive particles to be applied to the unit area, thus reducing the roughness or waviness to occur on the surface was expected (Karakurt et al. 2010). In contrast, it was stated that the effect of feed rate, abrasive flow rate, and the material thickness on the surface roughness of the medium-density fiberboards cut using AWJ is insignificant (Kvietkova et al. 2014). 
Table 4. Duncan's Test Results for Mean of $R_{z}$ Values

\begin{tabular}{|c|c|c|c|c|c|c|}
\hline \multirow[b]{2}{*}{ Factor } & \multicolumn{2}{|c|}{ Scotch Pine } & \multicolumn{2}{|c|}{ Eastern Beech } & \multicolumn{2}{|c|}{ Sessile Oak } \\
\hline & $\begin{array}{c}\text { Mean } \\
(\mu \mathrm{m})\end{array}$ & SG & $\begin{array}{c}\text { Mean } \\
(\mu \mathrm{m})\end{array}$ & SG & $\begin{array}{c}\text { Mean } \\
(\mu \mathrm{m})\end{array}$ & SG \\
\hline \multicolumn{7}{|c|}{ Cutting Direction and Thickness (mm) } \\
\hline R-18 & 39.25 & $\mathrm{~d}$ & 32.39 & $\mathrm{e}$ & 32.10 & $f$ \\
\hline R-36 & 42.36 & C & 35.99 & C & 37.05 & $\mathrm{~d}$ \\
\hline $\mathrm{R}-54$ & 48.98 & $\mathrm{~b}$ & 44.49 & a & 44.36 & $\mathrm{~b}$ \\
\hline $\mathrm{T}-18$ & 39.15 & d & 30.07 & $f$ & 33.73 & $\mathrm{e}$ \\
\hline T-36 & 43.14 & $c$ & 34.52 & d & 39.37 & $c$ \\
\hline $\mathrm{T}-54$ & 53.26 & $\mathrm{a}$ & 41.51 & $\mathrm{~b}$ & 51.92 & $\mathrm{a}$ \\
\hline \multicolumn{7}{|c|}{ Feed Speed $(\mathrm{mm} / \mathrm{min})$} \\
\hline 50 & 37.35 & $\mathrm{c}$ & 29.49 & C & 33.21 & $c$ \\
\hline 100 & 42.36 & $\mathrm{~b}$ & 35.77 & $\mathrm{~b}$ & 39.58 & $\mathrm{~b}$ \\
\hline 200 & 53.36 & $\mathrm{a}$ & 44.22 & $\mathrm{a}$ & 46.48 & $\mathrm{a}$ \\
\hline \multicolumn{7}{|c|}{ Abrasive Flow Rate (g/min) } \\
\hline 200 & 45.80 & $a$ & 38.93 & $a$ & 41.21 & $a$ \\
\hline 300 & 44.49 & $b$ & 36.27 & $b$ & 40.41 & $b$ \\
\hline 450 & 42.78 & $C$ & 34.28 & C & 37.65 & C \\
\hline \multicolumn{7}{|c|}{ Liquid Pressure (MPa) } \\
\hline 300 & 45.35 & $a$ & 35.31 & $b$ & 40.18 & $a$ \\
\hline 380 & 43.36 & $\mathrm{~b}$ & 37.67 & $a$ & 39.33 & $\mathrm{~b}$ \\
\hline
\end{tabular}

SG: statistical group (different letters denote a significant difference); R: radial; T: tangential

With respect to cutting liquid pressure in the AWJ cutting, in pine and oak specimens, the average values of $R_{\mathrm{a}}$ and $R_{\mathrm{z}}$ were lower under a pressure of $380 \mathrm{MPa}$ compared to a pressure of $300 \mathrm{MPa}$. However, the difference between $R_{\mathrm{a}}$ values in oak specimens was statistically insignificant. In beech specimens, the average values of $R_{\mathrm{a}}$ and $R_{\mathrm{z}}$ were lower under a pressure of $300 \mathrm{MPa}$ compared to a pressure of $380 \mathrm{MPa}$ (Tables 3 and 4). Depending on the increase in cutting liquid pressure, in pine and oak specimens, the $R_{\mathrm{a}}$ and $R_{\mathrm{z}}$ roughness values generally tended to decrease. In beech specimens, the opposite was true (Figs. 4 and 5).

The textural structure of the beech specimens may have had an effect on the results. In pine and oak specimens cut under a pressure of $380 \mathrm{MPa}$, compared to $300 \mathrm{MPa}$, the $R_{\mathrm{a}}$ values decreased $5 \%$ and $1 \%$, respectively, and the $R_{\mathrm{z}}$ values decreased $4 \%$ and $2 \%$, respectively. In beech specimens, with the increase in the liquid pressure, the $R_{\mathrm{a}}$ and $R_{\mathrm{Z}}$ values increased $6 \%$ and $7 \%$, respectively. In a previous study, it was reported that the roughness is somewhat reduced by increasing liquid pressure during the cutting of recombinant bamboo using AWJ (Li et al. 2015). Xie et al. (2020) determined that the factors affecting the surface roughness of red oak and bamboo specimens cut with AWJ system are ranked as follows: cutting pressure $>$ feed rate $>$ abrasive flow rate $>$ target distance > air-dry density. In addition, it has been stated that the liquid pressure has the most important effect on the surface quality of three hardwood types (okan, iroko, and merbau) cut using AWJ (Wang 2012). In contrast, it is stated that the cutting liquid pressure is more effective against the occurrence of traces in the form of lines or waviness on the surface rather than the surface roughness of the material. It was also reported that the waviness rate on the surface increases if the liquid pressure increases but does not cause a significant change in the surface roughness (Shipway et al. 2005; Karakurt et al. 2010). 


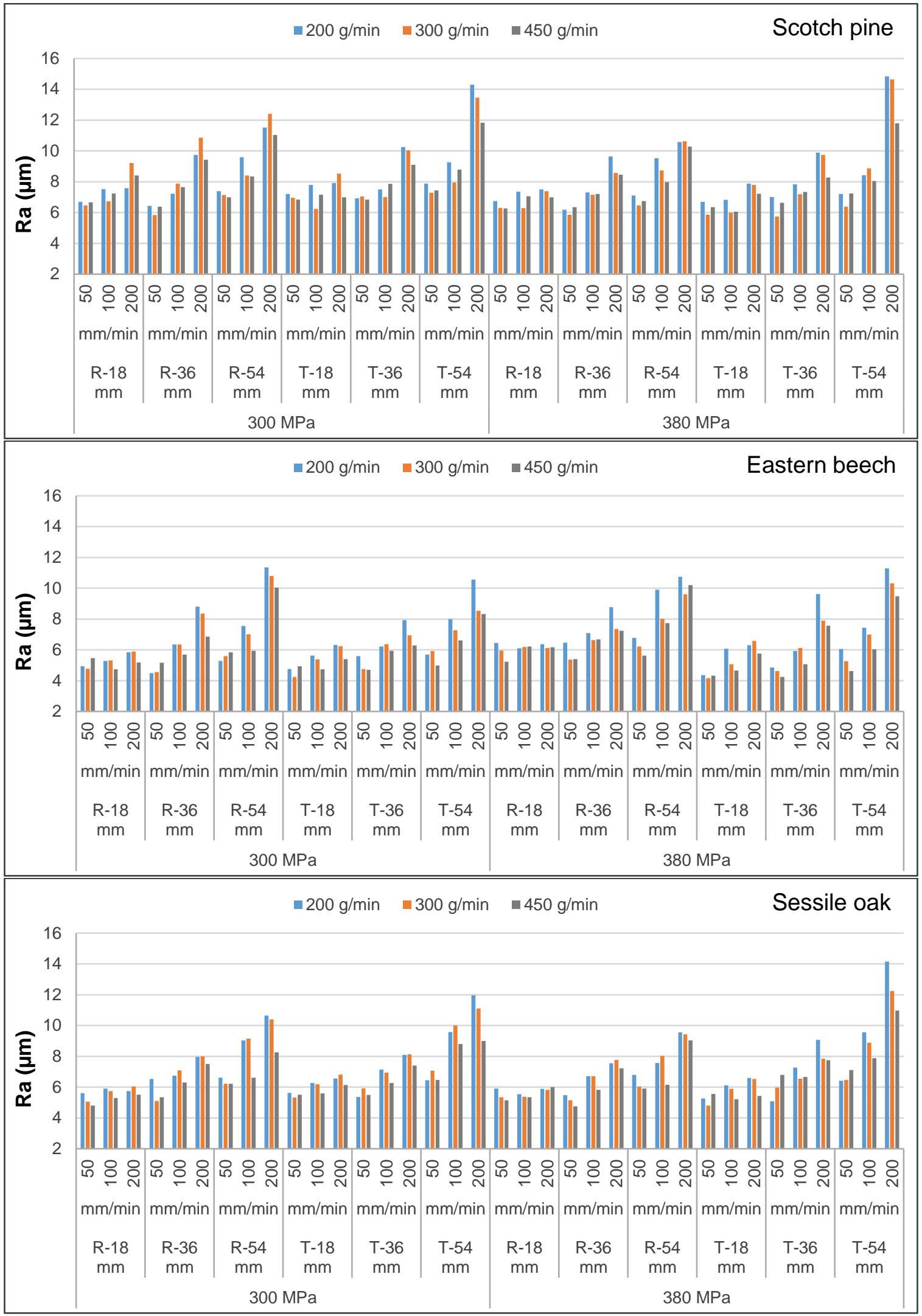

Fig. 4. The $R_{a}$ values of pine, beech, and oak woods cut with different processing parameters in the AWJ system 


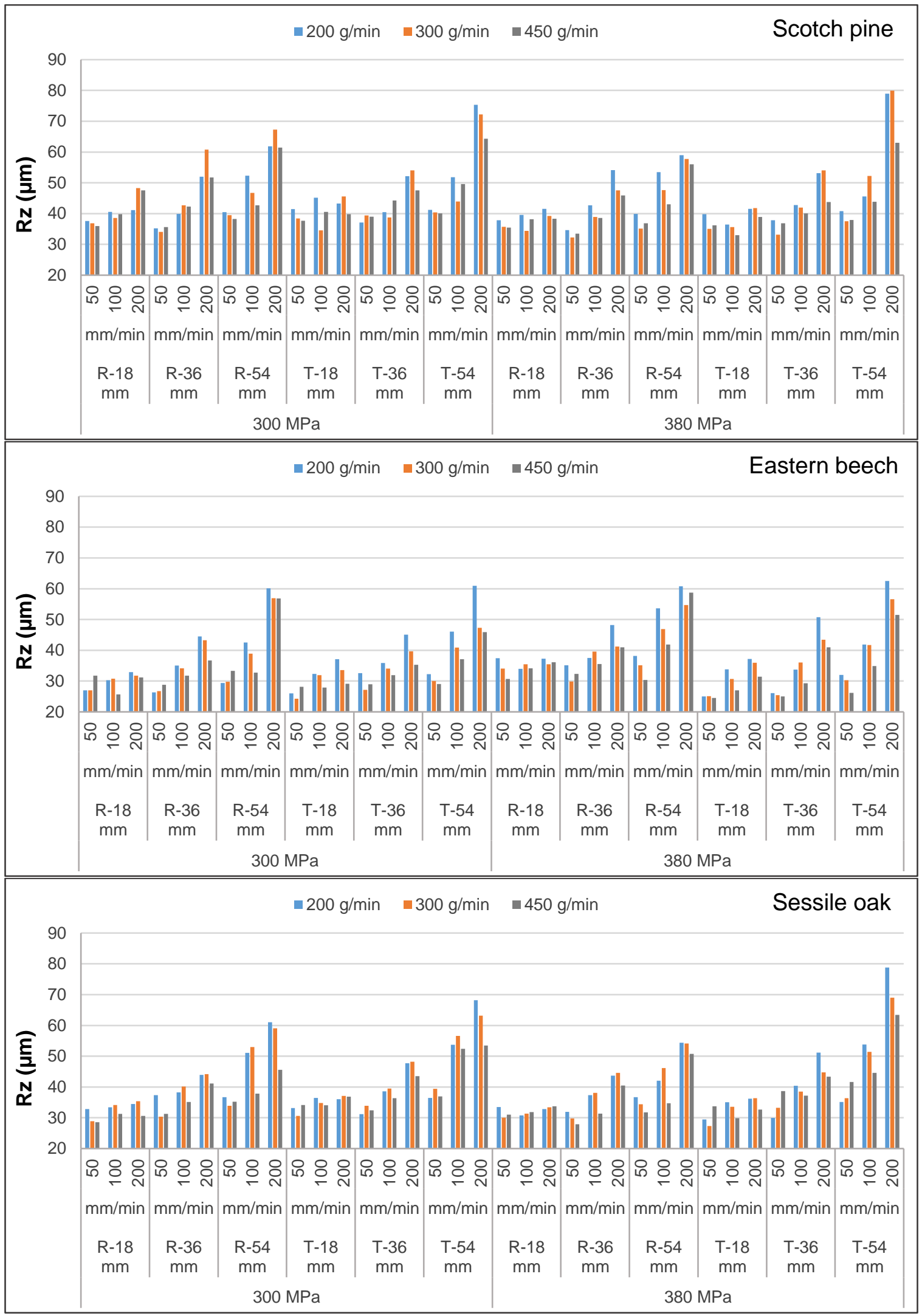

Fig. 5. The $R_{z}$ values of pine, beech, and oak woods cut with different processing parameters in the AWJ system 


\section{CONCLUSIONS}

1. The effect of different processing parameters on the surface roughness properties of pine, beech, and oak woods cut with AWJ cutting system was investigated. With the increase in the thickness of the wood specimens, the $R_{\mathrm{a}}$ and $R_{\mathrm{Z}}$ values also increased. Compared to the specimens of $18 \mathrm{~mm}$, in the specimens with a thickness of $54 \mathrm{~mm}$ the $R_{\mathrm{a}}$ and $R_{\mathrm{z}}$ increased $49 \%$ and $46 \%$, respectively. Additionally, the $R_{\mathrm{a}}$ and $R_{\mathrm{z}}$ were determined to be higher in the tangentially cut specimens for pine, oak wood, and in the radially cut specimens for beech wood.

2. For all wood types, the $R_{\mathrm{a}}$ and $R_{\mathrm{z}}$ roughness values increased due to the increase in the AWJ system feed rate. Compared to the feed rate of $50 \mathrm{~mm} / \mathrm{min}$, the $R_{\mathrm{a}}$ and $R_{\mathrm{z}}$ values of the specimens cut at a feed rate of $200 \mathrm{~mm} / \mathrm{min}$ increased $53 \%$ and $50 \%$, respectively.

3. As a result of the increase in the amount of abrasive added to the pressurized water, $R_{\mathrm{a}}$ and $R_{\mathrm{Z}}$ decreased in general and surface smoothness of the specimens increased. Compared to the abrasive flow rate of $200 \mathrm{~g} / \mathrm{min}$, the $R_{\mathrm{a}}$ and $R_{\mathrm{Z}}$ values of the specimens processed at an abrasive flow rate of $450 \mathrm{~g} / \mathrm{min}$ decreased $13 \%$ and $12 \%$, respectively.

4. Depending on the increase in cutting liquid pressure, the $R_{\mathrm{a}}$ and $R_{\mathrm{z}}$ values generally tended to decrease in pine and oak specimens. There was an increase in beech specimens. In pine and oak specimens cut under a pressure of $380 \mathrm{MPa}$ compared to $300 \mathrm{MPa}$, the $R_{\mathrm{a}}$ and $R_{\mathrm{z}}$ values decreased up to $5 \%$ and $4 \%$, respectively. In beech specimens, with the increase in the liquid pressure the $R_{a}$ and $R_{\mathrm{Z}}$ values increased $6 \%$ and $7 \%$, respectively.

5. As a result, while the feed rate and wood thickness factors on the roughness values of wood specimens cut using the AWJ system have primary importance, the cutting liquid pressure factor has the least importance.

\section{ACKNOWLEDGMENTS}

The authors are grateful for the support of the Research Fund of Duzce University, Grant No. BAP-2017.07.01.521.

\section{REFERENCES CITED}

Ábrahám, J., Bak, M., and Németh, R. (2015). "The effect of high pressure water jet on the surface quality of wood," Pro Ligno 11(4), 471-477.

Akkurt, A. (2004). "Waterjet cutting systems and assessment of their industrial applications," Journal of Polytechnic 7(2), 129-139.

Akkurt, A., Kulekci, M. K., Seker, U., and Ercan, F. (2004). "Effect of feed rate on surface roughness in abrasive waterjet cutting applications," Journal of Materials Processing Technology 147(3), 389-396. DOI: 10.1016/j.jmatprotec.2004.01.013

Aydın, G., Karakurt, I., and Aydıner, K. (2011). "An investigation on surface roughness of granite machined by abrasive water jet," Bulletin of Materials Science 34(4), 985992. DOI: $10.1007 / \mathrm{s} 12034-011-0226-\mathrm{x}$ 
Barcík, Š., Kvietková, M., and Aláč, P. (2011a). "Effect of the chosen parameters on deflection angle between cutting sides during the cutting of agglomerated materials by water jet," Wood Research 56(4), 577-588.

Barcík, Š., Kvietková, M., Kminiak, R., and Aláč, P. (2011b). “Optimization of cutting process of medium density fibreboards by the abrasive water-jet," Drvna Industrija 62(4), 263-268. DOI: 10.5552/drind.2011.1113

Budakçı, M., İlçe, A. C., Korkut, D. S., and Gürleyen, T. (2011). "Evaluating the surface roughness of heat-treated wood cut with different circular saws," BioResources 6(4), 4247-4258. DOI: 10.15376/biores.6.4.4247-4258

Gerencsér, K., and Bejó, L. (2007). "Investigations into the water jet cutting of solid wood," Wood Research 52(2), 57-64.

Hascalik, A., Çaydaş, U., and Gürün, H. (2007). "Effect of traverse speed on abrasive waterjet machining of Ti-6Al-4V alloy," Materials \& Design 28(6), 19531957. DOI: $10.1016 /$ j.matdes.2006.04.020

Hashish, M. (1987). "Turning with abrasive-waterjets-A first investigation," Jounal of of Engineering for Industry 109(4), 281-290. DOI: 10.1115/1.3187130

Hazir, E., Koc, K. H., and Hiziroglu, S. (2017). "Optimization of sanding parameters using response surface methodology," Maderas. Ciencia y Tecnologia 19(4), 407416. DOI: $10.4067 / S 0718-221 X 2017005000101$

Hiziroğlu, S., Zhong, Z. W., and Ong, W. K. (2014). "Evaluating of bonding strength of pine, oak and nyatoh wood species related to their surface roughness," Measurement 49, 397-400. DOI: 10.1016/j.measurement.2013.11.053

Hou, R., Huang, C., and Zhu, H. (2014). "Numerical simulation ultrahigh waterjet (WJ) flow field with the high-frequency velocity vibration at the nozzle inlet," The International Journal of Advanced Manufacturing Technology 71(5-8), 1087-1092. DOI: $10.1007 / \mathrm{s} 00170-013-5493-9$

Hutyrová, Z., Ščučka, J., Hloch, S., Hlaváček, P., and Zeleňák, M. (2016). “Turning of wood plastic composites by water jet and abrasive water jet," The International Journal of Advanced Manufacturing Technology 84(5-8), 1615-1623. DOI: 10.1007/s00170-015-7831-6

ISO 4287 (1997). “Geometrical product specifications (GPS) - Surface texture: Profile method - Terms, definitions and surface texture parameters," International Organization for Standardization, Geneva, Switzerland.

ISO 13061-2 (2014). "Physical and mechanical properties of wood - Test methods for small clear wood specimens - Part 2: Determination of density for physical and mechanical tests," International Organization for Standardization, Geneva, Switzerland.

İlçe, A. C. (2018). "Determination of surface roughness based on the sanding parameters of oriental beech wood," BioResources 13(3), 5942-5952. DOI:

10.15376/biores.13.3.5942-5952

Karakurt, İ., Aydın, G., and Aydıner, K. (2010). "Effect of cutting parameters on the surface roughness of granite in abrasive waterjet cutting," Journal of the Earth Sciences Application and Research Centre of Hacettepe University 31(2), 99-110.

Kilıç, M., Hiziroglu, S., and Burdurlu, E. (2006). "Effect of machining on surface roughness of wood," Building and Environment 41(8), 1074-1078. DOI: 10.1016/j.buildenv.2005.05.008 
K1lıç, M. (2015). "Effects of machining methods on the surface roughness values of Pinus nigra Arnold wood," BioResources 10(3), 5554-5562. DOI: 10.15376/biores.10.3.5554-5562

Kminiak, R., and Gaff, M. (2014). "Fabrication of structural joinery items of solid wood by the mean of abrasive water jet method," Wood Research 59(3), 499-507.

Kvietkova, M., Barcík, Š., Bomba, J., and Aláč, P. (2014). "Impact of chosen parameters on surface undulation during the cutting of agglomerated materials with an abrasive water jet," Drewno: Prace Naukowe, Doniesienia, Komunikaty 57(191), 111-123. DOI: 10.12841/wood.1644-3985.017.08

Kvietková, M. (2014). "Topography of material made by the application of abrasive water jet technology," Journal of Forest Science 60(8), 318-323.

Li, M., Cao, Y., Wang, Z., and Wang, Y. (2018a). "Optimization and analysis of processing parameters of wooden crafts based on ultra-high pressure water jet method," Wood Research 63(1), 117-126.

Li, M., Xie, W., Wang, C. X., Cao, Y., and Wang, Z. (2018b). "Parameters optimization for ultrahigh-pressure pure water and abrasive water jet of Pterocarpus macarocarpus Kurz processing," Wood Research 63(5), 783-794.

Li, R., Ekevad, M., Guo, X., Cao, P., Wang, J., Chen, Q., and Xue, H. (2015). "Pressure, feed rate, and abrasive mass flow rate influence on surface roughness for recombinant bamboo abrasive water jet cutting," BioResources 10(2), 1998-2008. DOI:

10.15376/biores.10.2.1998-2008

Li, W., Zhu, H., Wang, J., Ali, Y. M., and Huang, C. (2013). "An investigation into the radial-mode abrasive waterjet turning process on high tensile steels," International Journal of Mechanical Sciences 77, 365-376. DOI: 10.1016/j.ijmecsci.2013.05.005

Oh, T. M., and Cho, G. C. (2014). "Characterization of effective parameters in abrasive water jet rock cutting," Rock Mechanics and Rock Engineering 47(2), 745-756. DOI: 10.1007/s00603-013-0434-3

Ohlsson, L. (1995). The Theory and Practice of Abrasive Water Jet Cutting, Ph.D. Dissertation, Division of Materials Processing, Lulea University of Technolagy, Lulea, Sweden.

Örs, Y., and Gürleyen, L. (2002). "Effect of the cutting direction, number of cutter and cutter type to surface smoothness on wood material for planning," Journal of Polytechnic 5(4), 335-339.

Pinkowski, G., Szymański, W., Krauss, A., and Stefanowski, S. (2018). "Effect of sharpness angle and feeding speed on the surface roughness during milling of various wood species," BioResources 13(3), 6952-6962. DOI: 10.15376/biores.13.3.69526962

Richter, K., Feist, W. C., and Knaebe, T. K. (1995). "The effect of surface roughness on the performance of finishes. Part 1. Roughness characterization and stain performance," Forest Products Journal 45(7/8), 91-97.

Salca, E. A., Krystofiak, T., and Lis, B. (2017). "Evaluation of selected properties of alder wood as functions of sanding and coating," Coatings 7(10), 1-10. DOI: $10.3390 /$ coatings 7100176

Saraçyakupoğlu, T. (2012). Analysis of Material, Pressure, Cutting Velocity and Water Jet Diameter's Effect on the Surface Quality for the Water Jet Cutting, Ph.D. Dissertation, Eskişehir Osmangazi University, Eskişehir, Turkey. 
Shanmughasundaram, P. (2014). "Influence of abrasive water jet machining parameters on the surface roughness of eutectic Al-Si alloy-graphite composites," Materials Physics and Mechanics 19(1), 1-8.

Shipway, P. H., Fowler, G., and Pashby, I. R. (2005). "Characteristics of the surface of a titanium alloy following milling with abrasive waterjets," Wear 258(1-4), 123-132. DOI: 10.1016/j.wear.2004.04.005

Sieminski, R., and Skarzynska, A. (1987). "Surface roughness of different species of wood after sanding," Przemysl Drzewny 38(9), 23-25.

Sreekesh, K., and Govindan, P. (2014). "A review on abrasive water jet cutting," International Journal of Recent Advances in Mechanical Engineering 3(3), 153-158. DOI: 10.14810/ijmech.2014.3313

Sofuoğlu, S. D., and Kurtoğlu, A. (2015). "Effects of machining conditions on surface roughness in planing and sanding of solid wood," Drvna Industrija 66(4), 265-272. DOI: $10.5552 /$ drind.2015.1406

Söğütlü, C., Nzokou, P., Koc, I., Tutgun, R., and Döngel, N. (2016). “The effects of surface roughness on varnish adhesion strength of wood materials," Journal of Coatings Technology and Research 13(5), 863-870. DOI:10.1007/s11998-016-9805-5

Söğütlü, C. (2017). "Determination of the effect of surface roughness on the bonding strength of wooden materials," BioResources 12(1), 1417-1429. DOI: 10.15376/biores.12.1.1417-1429

Tiryaki, S. (2014). "Effecting factors on surface roughness in wood machining," Turkish Journal of Forestry 15(2), 176-182.

Wang, Z. (2012). "An investigation on water jet machining for hardwood floors," European Journal of Wood and Wood Products 70(1-3), 55-59. DOI: 10.1007/s00107-010-0492-0

Xie, W., Fang, J., Wang, Z., and Huang, L. (2020). “Optimization of technological parameters of water jet cutting of red oak and bamboo based on three-dimensional surface topography measurement," BioResources 15(2), 3270-3277. DOI: 10.15376/biores.15.2.3270-3277

Youssef, H. A. (2016). "Machining of stainless steels and super alloys: traditional and nontraditional techniques," John Wiley \& Sons, Hoboken, NJ, USA, pp. 179-219.

Zhong, Z. W., and Han, Z. Z. (2002). "Turning of glass with abrasive waterjet," Materials and Manufacturing Processes 17(3), 339-349. DOI: 10.1081/AMP120005380

Article submitted: April 26, 2020; Peer review completed: June 13, 2020; Revised version received and accepted: June 19, 2020; Published: June 24, 2020.

DOI: 10.15376/biores. 15.3.6135-6148 